Article

\title{
Susceptibility Assessments of Landslides in Hulu Kelang Area Using a Geographic Information System-Based Prediction Model
}

\author{
Sangseom Jeong ${ }^{1}$, Azman Kassim ${ }^{2}$, Moonhyun Hong ${ }^{1, *(1)}$ and Nader Saadatkhah ${ }^{3}$ (D) \\ 1 School of Civil and Environmental Engineering, Yonsei University, Seoul 03722, Korea; soj9081@yonsei.ac.kr \\ 2 Department of Geotechnics and Transportation, Universiti Teknologi Malaysia, Johor Bahru 81310, Malaysia; \\ azmankassim@utm.my \\ 3 Department of Civil Engineering, Faculty of Engineering, Islamic Azad University (IAU), Kerman Branch, \\ Kerman 761, Iran; n_saadat_khah@hotmail.com \\ * Correspondence: homh12@naver.com; Tel.: +82-2-2123-8373
}

Received: 13 July 2018; Accepted: 13 August 2018; Published: 19 August 2018

check for updates

\begin{abstract}
This study was conducted to estimate the susceptibility of landslides on a test site in Malaysia (Hulu Kelang area). A Geographic Information system (GIS)-based physical model named YS-Slope, which integrates a mechanistic infinite slope stability method and the geo-hydrological model was applied to calculate the safety factor of the test site. Input data, slopes, soil-depth, elevations, soil properties and plant covers were constructed as GIS datasets. The factor of safety of shallow landslides along the wetting front and deep-seated landslides at the bottom of the groundwater were estimated to compare with the analysis results of the existing model and actual landslides in 2008. According to the results of the study, shallow landslides mainly occurred in the central area which has many historical landslides, while deep-seated landslides were predominant in the east side of the study area. A ROC analysis was conducted and it is shown that the prediction result at the end of the northeast monsoon for shallow landslides showed relatively high accuracy compared with other predictions.
\end{abstract}

Keywords: landslide susceptibility; rainfall-induced landslide; physical model; groundwater flow

\section{Introduction}

A landslide is one of the most serious disasters that can occur in an urban area but since there is no clear solution yet, landslides are causing damage to lives and properties. Recently, various studies have been carried out to reduce damages caused by landslides and to increase the sustainability of urban areas including several studies on safety and economic feasibility against landslides [1]. Wang et al. (2015) conducted a susceptibility assessment of landslides in Boaxing Catchment, Sichuan, China, based on a Geographical Information System (GIS) and an Area Under Receiver operating Characteristic Curve (AUC) [2]. Zhou et al. (2016) integrated the subjective weight and objective weight for regional landslides susceptibility analysis based on GIS [3]. Additionally, a study on cost of damage and effect of adaptation to landslides by considering climate change was conducted to relate landslides with climate change [4]. Hulu Kelang has reported 28 major landslides from 1990 to 2011 and is very vulnerable to landslides in Malaysia [5]. Malaysia region is temperately situated in the monsoon zone that is generally hot and humid with heavy rainfall events in rainy seasons and landslides in Malaysia occur usually during the rainy seasons.

Landslides susceptibility assessments can generally be categorized into four groups: landslides inventory, statistical, heuristic and deterministic methods [6-15]. The inventory method is one of the 
simplest approaches to assess landslide risk using historical landslide occurrence maps. The inventory analysis, however, has a disadvantage that the risk cannot be assessed in areas where there is no history of landslides. The heuristic method is generally used to assess the landslide susceptibility from the historical data of the preparatory variables derived from landslide occurrence histories. This method is mainly used to analyze the reproducibility of landslides and the weights of the preparatory variables based on the assumption which the relationship between the landslide risk and the variables has been identified and is well reflected in the model [16]. Statistical techniques are generally used to predict the occurrence of landslides by using sufficient information on parameters that can be considered to be related to landslides $[17,18]$. Statistical methods and deterministic methods are both used to assess the susceptibility of landslides based on the parameters that affect slope stabilities $[19,20]$. However, several historical landslides data are needed to propose a statistical method [21].

Physically-based models were proven its applicability globally and many researchers have studied the causes of rainfall-induced landslides by means of laboratory and field tests and numerical analysis. They suggested a landslides mechanism that occurs frequently when the matric suction of the soil and the effective stress are reduced by the formation of wetting fronts due to rainfall-infiltrations [22-27]. According to previous studies, landslides are caused by external factors such as increased stress or hydraulic coupling processes, which can change slope stability conditions. Based on the landslide mechanisms, local scale methods had been proposed to predict landslides considering the topography, geological, hydrological parameters and plant covers [28,29]. Landslide susceptibility assessments for the regional scale before the occurrence of landslides can provide useful information to prevent landslides losses [30].

There are several methods of the landslide susceptibility assessment. Implementing data for landslide factors, such as weather condition, topography and vegetation, using GIS tools can be the basic data for a regional landslide susceptibility assessment [9]. Because of the efficiency of GIS in the processing of dispersed spatial data, GIS is usually used for wide-area landslide analysis [15,31-36]. These regional-scale models can take into account the relationship between the spatial distribution of rainfall and landslides. In particular, physical methods are used to determine when and where landslides occur by combining hydrological and geotechnical models based on several mechanisms of rainfall-induced landslides.

In conclusion, to reduce landslide damages, regional scale landslide susceptibility assessments should be carried out and combinations of hydrological theory and geotechnical theory based on landslide mechanisms are needed. In this study, based on Digital Elevation Model (DEM), rainfall characteristics, hydrological parameters and geotechnical and mechanical soil properties of the study area in Malaysia, the assessment of landslides susceptibility on Hulu Kelang area was conducted by using a GIS-based physically-based model and compared with the analysis results of existing model and actual landslides in 2008.

\section{Methodology and Materials}

\subsection{YS-Slope Model}

Kim et al. (2014) developed a GIS-based physical landslides prediction model (called YS-Slope) that takes into account not only generations of the wetting front by rainfall-infiltrations but also groundwater recharges and flows. The YS-Slope model can also consider vegetation conditions. In this study, the landslides susceptibility assessment of the study area was conducted and analyzed by using the YS-Slope model. The YS-Slope model had been developed using the methodological process as shown in Figure 1. This model uses hydrological unsaturated soil properties such as the field matric suction and Soil Water Characteristic Curve (SWCC), as well as the geotechnical soil strength properties such as the internal friction angle and the cohesion.

The general mechanism of rainfall-induced landslides can be classified into three cases: (1) failure along the wetting front (shallow failure); (2) failure at the bottom of the groundwater; and (3) failure 
affected both of wetting front and the groundwater recharge (deep-seated failure). In this study, the infinite slope failure model was applied as a physical limit equilibrium to calculate safety factors of rainfall-induced landslides. In addition, the model reflects the influence of the increased soil strength and load and interception loss due to vegetation by modifying the infinite slope stability equation as follows:

$$
\begin{gathered}
\mathrm{FS}=\frac{\left(\mathrm{c}_{\mathrm{S}}^{\prime}+\mathrm{c}_{\mathrm{r}}^{\prime}\right)+\left[\left(\gamma_{\mathrm{sat}}-\gamma_{\mathrm{w}}\right) \cdot \mathrm{Z}_{\mathrm{w}}+\mathrm{q}_{0}\right] \cos ^{2} \beta \cdot \tan \phi^{\prime}}{\left(\gamma_{\mathrm{sat}} \cdot \mathrm{D}_{\mathrm{w}}+\mathrm{q}_{0}\right) \cdot \sin \beta \cdot \cos \beta} \text { (Shallow failure) } \\
\mathrm{FS}=\frac{\left(\mathrm{c}_{\mathrm{s}}^{\prime}+\mathrm{c}_{\mathrm{r}}^{\prime}\right)+\left[\left(\gamma_{\mathrm{sat}}-\gamma_{\mathrm{w}}\right)\left(\mathrm{Z}_{\mathrm{w}}+\mathrm{D}_{\mathrm{w}}\right)+\gamma_{\mathrm{t}} \cdot\left(\mathrm{D}-\mathrm{Z}_{\mathrm{w}}-\mathrm{D}_{\mathrm{w}}\right)+\mathrm{q}_{0}\right] \cos ^{2} \beta \cdot \tan \phi^{\prime}}{\left[\gamma_{\mathrm{sat}} \cdot\left(\mathrm{Z}_{\mathrm{w}}+\mathrm{D}_{\mathrm{w}}\right)+\gamma_{\mathrm{t}} \cdot\left(\mathrm{D}-\mathrm{Z}_{\mathrm{w}}-\mathrm{D}_{\mathrm{w}}\right)+\mathrm{q}_{0}\right] \cdot \sin \beta \cdot \cos \beta}(\text { Deep - seated failure })
\end{gathered}
$$

where $c_{s}^{\prime}$ is soil cohesion, $c_{r}^{\prime}$ is the shear strength increase by root reinforcement, $\gamma_{\mathrm{sat}}$ is saturated unit weight of soils, $\gamma_{\mathrm{w}}$ is unit weight of water, $\gamma_{\mathrm{t}}$ is total unit weight of soils, $\mathrm{q}_{0}$ is the forest tree load, $Z_{\mathrm{w}}$ is wetting front depth, $D_{w}$ is groundwater table from the bedrock, $D$ is the thickness of dry soil, $\phi^{\prime}$ is internal friction angle of soil and $\beta$ is slope inclination. Plant cover conditions are applied as forest tree load and the shear strength increase by root reinforcement. The forest tree load strengthens both the driving force and resistance force while the root reinforcement only increases resistance force.

These input data, DEM and soil depth of the regional area are entered as raster data of the matrix structure. The infinite slope failure model is used to analyze the slope stability represented by the safety factor and hydrological analysis is performed to simulate rainfall-infiltration and the groundwater recharge and flows. Various types of rainfall events such as real-time precipitation and probability rainfalls can be used in the analysis [37].

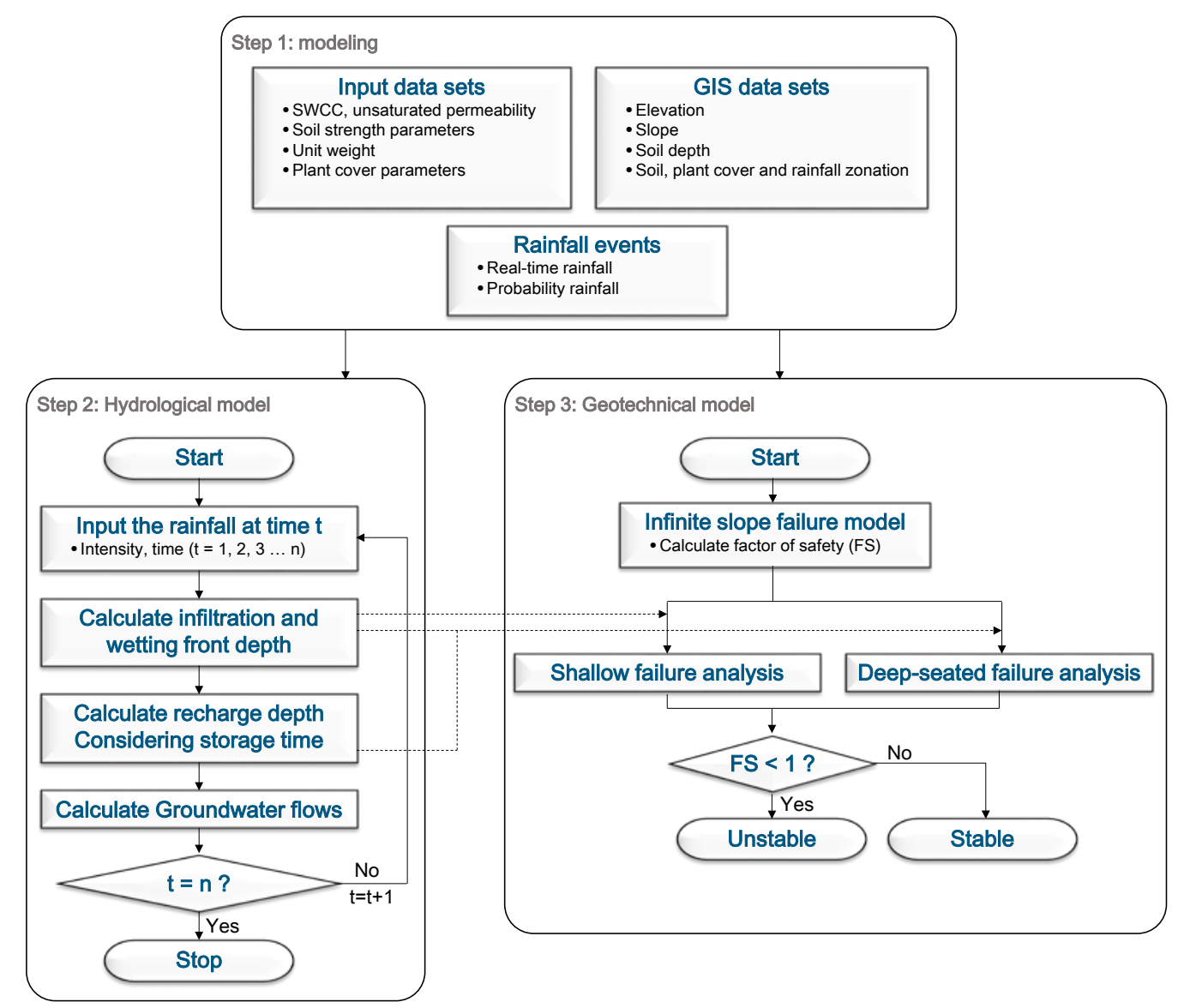

Figure 1. Process of landslide susceptibility assessment in YS-Slope model. 
A modified Green and Ampt model [38,39] was used to estimate rainfall-infiltration and groundwater recharge considering the behavior of the unsaturated soil. There are three assumptions in the hydrological model: (1) the aquifer and soils are homogeneous; (2) the recharge changes spatially and temporally; and (3) the groundwater flows are only under the ground surface.

Groundwater flow was calculated by linking the GIS-based raster model with Darcy's law [40] and recharge by rainfall-infiltration was used as an input variable. The modified Green-Ampt model was used for rainfall-infiltration analysis, suggested as an infiltration model for homogeneous soil with uniform water content under ponded conditions [38]. The modified Green-Ampt model was transformed into a method more suitable for modeling the infiltration. Groundwater flow analysis was performed on small unit volumes assumed to be homogeneous in soil characteristics. The fluxes were calculated to balance the masses of water entering the unit volume and the water flowing out, satisfying Darcy's law.

\subsection{Study Area}

Hulu Kelang is a residential area located in the northeast side of Kuala Lumpur, the capital of Malaysia, as shown in Figure 2. In this area, totally 28 major landslides had been reported from 1990 to 2011. The rainfall in this study area is characterized by two monsoons, the Southwest (SW) monsoon from May to September and the Northeast (NE) monsoon from November to March but the highest rainfall generally occurs in inter-monsoon season. From the soil investigations in previous studies, it was shown that this area rests on coarse-grained granite [41].
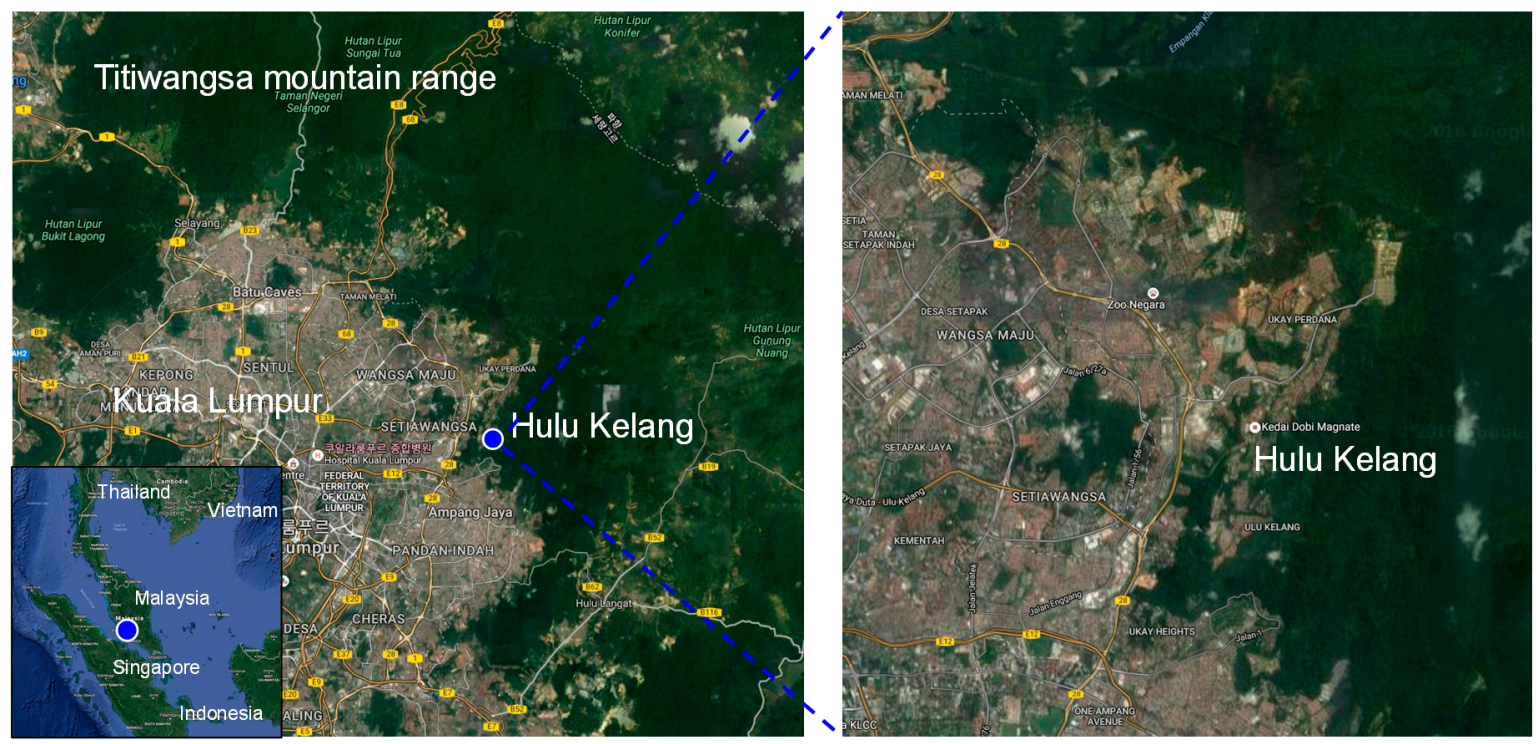

Figure 2. The location of Hulu Kelang area.

\subsubsection{Digital Elevation Model (DEM), Slope, Soil Depth and Groundwater Table}

As shown in Figure 3a, $30 \mathrm{~m}$ by $30 \mathrm{~m}$ pixel size of DEM was developed by the information provided from Department of Survey and Mapping Malaysia [42]. From the relationship between elevation and that of the surrounding cells, some useful information like the aspect and the slope can be derived. Based on Figure 3b, the slope map is classified based on 0 to 60 degrees, with elevations ranging from approximately 40 to $400 \mathrm{~m}$ above sea level. The soil depth is one of the important factors in the occurrence of landslides. Saadatkhah et al. (2014) presented the relationship between the soil depth and topographic elevation of the Hulu Kelang area based on the historical boreholes in the study area and the presented equation is as follows [5]:

$$
D=0.00968 \times h+17.326
$$


where $D$ is the soil depth and $h$ is the elevation. From Equation (3), the distribution of the soil depth was constructed, ranging from $17.5 \mathrm{~m}$ to $22.5 \mathrm{~m}$ as shown in Figure 3c. Stek (2008) presented an equation of the relationship between groundwater levels and topographic elevation based on the historical boreholes available from the Department of Surveying and Mapping Malaysia and the presented equation is as follows [43]:

$$
D_{w}=1.011 \times h \cdot 3.689
$$

where $D_{w}$ is the initial groundwater table and $h$ is the elevation. The map of groundwater table shown in Figure $3 \mathrm{~d}$ was applied as initial groundwater condition and the initial groundwater level distributed from $3.0 \mathrm{~m}$ to $19.5 \mathrm{~m}$ below the ground surface.

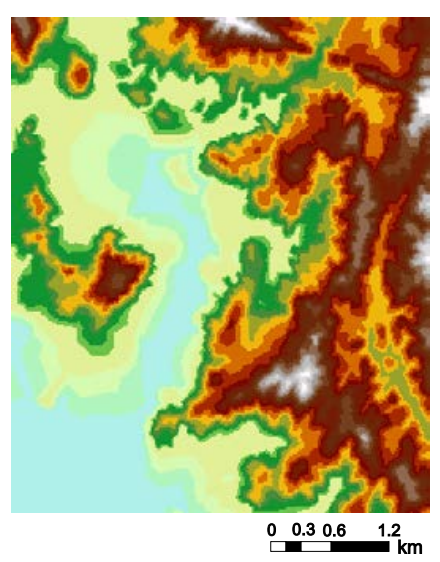

(a)

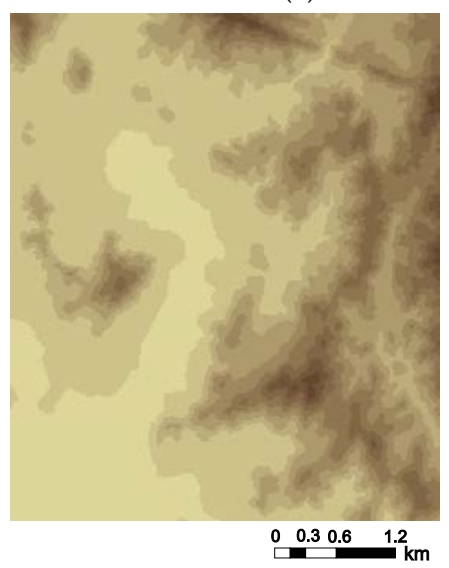

(c)

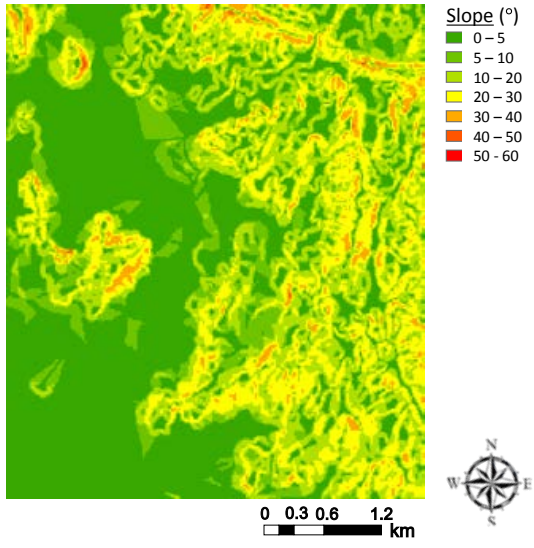

(b)

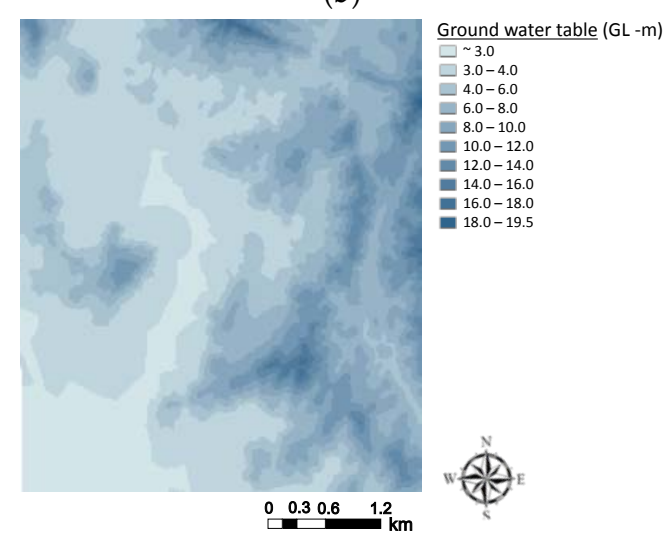

(d)

Figure 3. Topographic information of the study area. (a) Digital elevation model; (b) Map of slope; (c) Map of soil depth; (d) Map of groundwater table.

\subsubsection{Soil Properties and Zonation}

The residual soils of the study area were classified by using Selangor soil map obtained from Department of Irrigation and Drainage, Malaysia and according to the previous research on the study area, there are 1305 points of boreholes around the Kuala Lumpur, Malaysia [43]. Detailed soil mechanical and hydrological properties were obtained from the previous research based on the data obtained from the boreholes [38]. Residual soils over bedrock in the study area were classified by six different types: STP (Granite residual soil), LAACOL (Phyllite residual soil), Mum-SBN (Munchong Seremban association), DLD (Reformed area), RGM (Rengam series) and UDEVA (Urban development Area) as shown in Figure 4 [42]. The hydrological and geotechnical characteristics of residual soils were collected and built as GIS data from the Ministry of Agriculture 
and the Agro-Based Industry of Malaysia, the Slope Engineering Branch of Public Works Department Malaysia and Ampang Jaya Municipal Council, as well as data compiled from previously reported studies and Geotechnical boreholes. The series of relationships between matric suction and volumetric water content and the soil water characteristic curves of each zone, were assigned based on the van Genuchten equation, as shown in Figure 5. Strength properties of residual soils were assumed to be spatially invariant and were determined with Table 1.

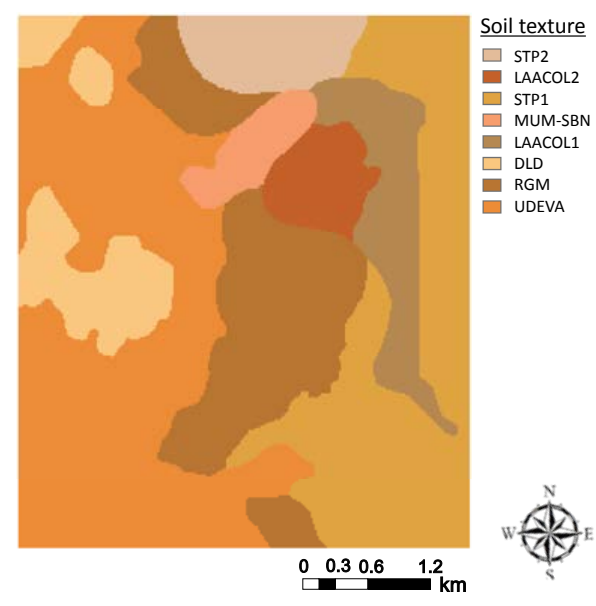

Figure 4. Soil zonation [42].

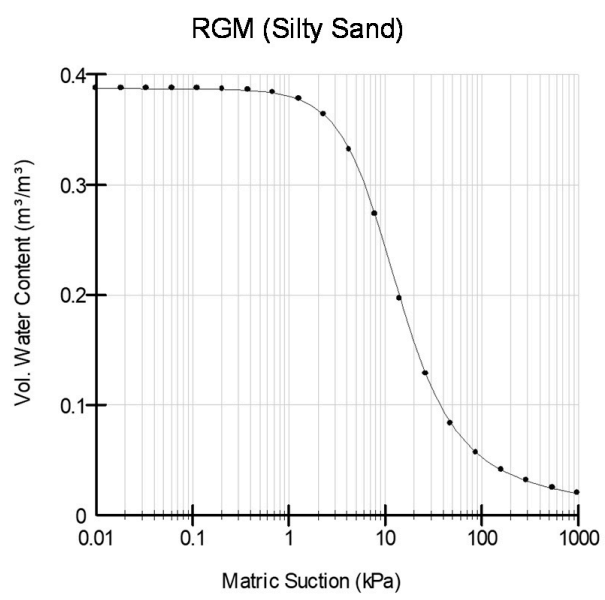

LAACOL (Clayey Sand)

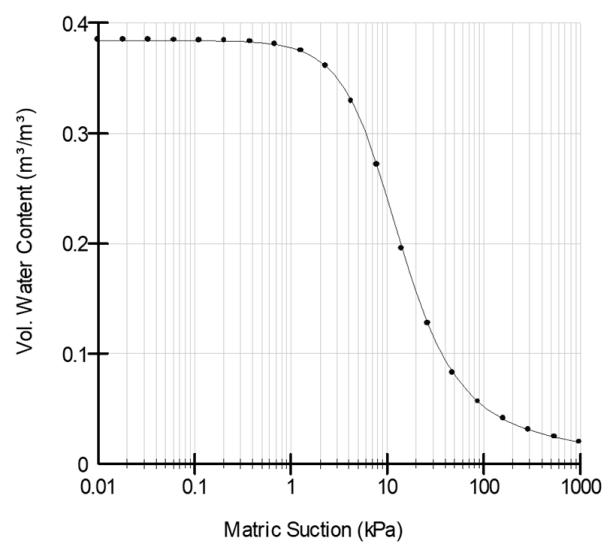

STP (Clay)

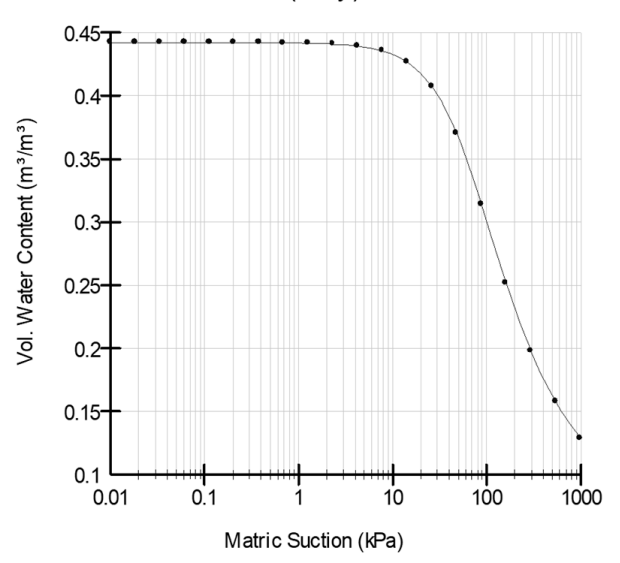

MUM-SBN (Fat Clay)

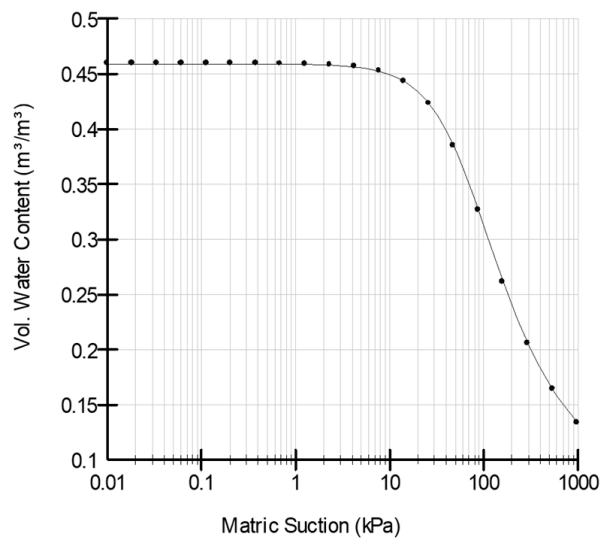

Figure 5. Cont. 

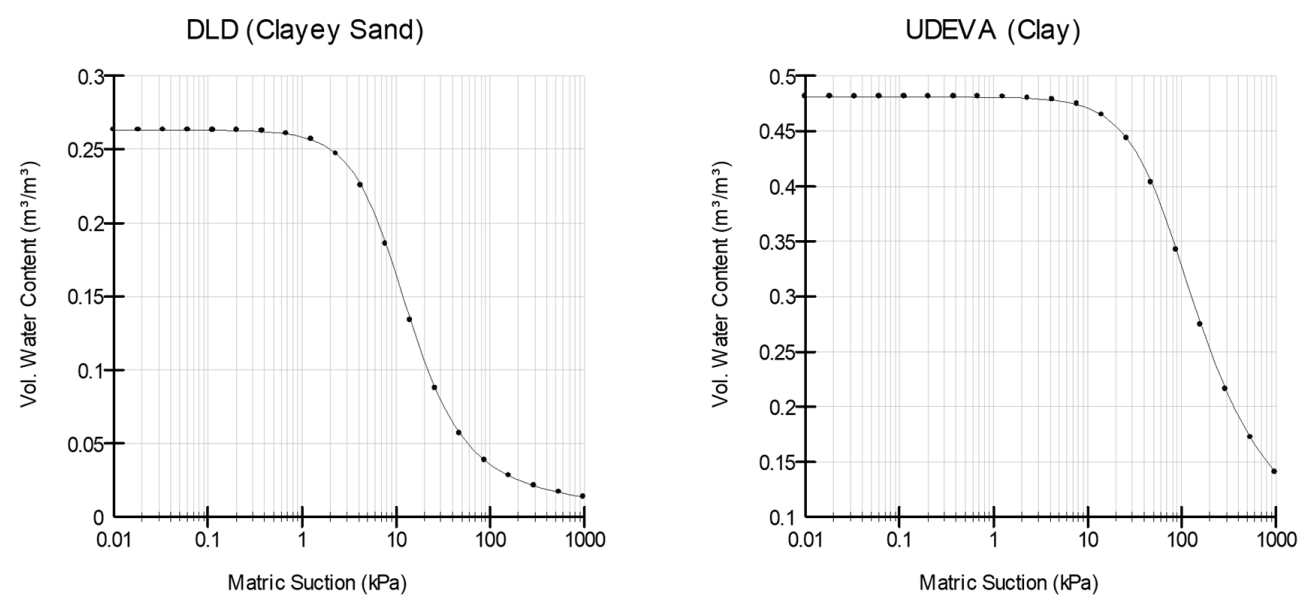

Figure 5. Soil-water characteristic curve of each soil zone.

Table 1. Soil properties of the study area.

\begin{tabular}{ccccccc}
\hline Soil Name & $\gamma_{\mathbf{s}}\left(\mathbf{k N} / \mathbf{m}^{\mathbf{3}}\right)$ & $\mathbf{C}^{\prime} \mathbf{( k P a )}$ & $\left.\boldsymbol{\varphi}^{\prime} \mathbf{(}^{\circ}\right)$ & $\mathbf{K}_{\mathbf{s}}(\mathbf{m} / \mathbf{s})$ & $\theta_{\mathbf{r}}$ & $\theta_{\mathbf{s}}$ \\
\hline STP2 & 14.1 & 23 & 31.5 & $9.47 \times 10^{-07}$ & 0.079 & 0.442 \\
LAACOL2 & 16.3 & 11 & 31 & $1.52 \times 10^{-06}$ & 0.063 & 0.384 \\
STP1 & 15.4 & 21 & 29 & $9.47 \times 10^{-07}$ & 0.079 & 0.442 \\
MUM-SBN & 13.7 & 26 & 23 & $1.71 \times 10^{-07}$ & 0.098 & 0.459 \\
LAACOL1 & 16.8 & 4 & 33 & $1.52 \times 10^{-06}$ & 0.063 & 0.384 \\
DLD & 15.7 & 5 & 32 & $1.40 \times 10^{-06}$ & 0.043 & 0.263 \\
RGM & 18.7 & 2 & 35 & $4.43 \times 10^{-06}$ & 0.039 & 0.387 \\
UDEVA & 14.8 & 22 & 28 & $1.11 \times 10^{-06}$ & 0.111 & 0.481 \\
\hline
\end{tabular}

\subsubsection{Plant Cover}

The main vegetation of Hulu Kelang is made up of lush rainforest. The plant cover maps of this study area were classified by Jabatan Ukur Dan Pemetaan Malaysia based on Anderson's system [44]. Depending on the classification system, nine types of flora have been found: primary forests, secondary jungles, rubber, bush trees, grass, clear land, recreation and recreation, urban areas and lakes (Figure 6). The tropical vegetation cover in the study area has a surcharge of 0 to $2.95 \mathrm{kN} / \mathrm{m}^{3}$ from the Department of Forestry (PWD) of the Malaysian Ministry of Agriculture (MOA) and the Malaysian Public Works Department (Table 2) [45-50]. The root cohesion of the plant cover ranged from 0 to $2.75 \mathrm{kPa}$ depending on the root density, species and soil characteristics [45-47].

Table 2. Plant cover characteristics.

\begin{tabular}{ccccc}
\hline Class & Root Cohesion $\mathbf{( k P a )}$ & Surcharge $\left(\mathbf{k N} / \mathbf{m}^{\mathbf{3}}\right)$ & LAI & Interception Loss $(\mathbf{\%})$ \\
\hline Primary forest & 2.75 & 2.95 & 3.99 & 24 \\
Secondary forest & 1.76 & 2.25 & 3.35 & 23 \\
Rubber & 0.3 & 1.35 & 2.29 & 19 \\
Sundry tree cultivation & 2.75 & 2.25 & 3.5 & 23 \\
Grass land & 0 & 0 & 1.49 & 17 \\
Cleared land & 0 & 0 & 0 & 0 \\
Developed area & 0 & 0 & 0 & 0 \\
Lake & 0 & 0 & 0 & 0 \\
\hline
\end{tabular}




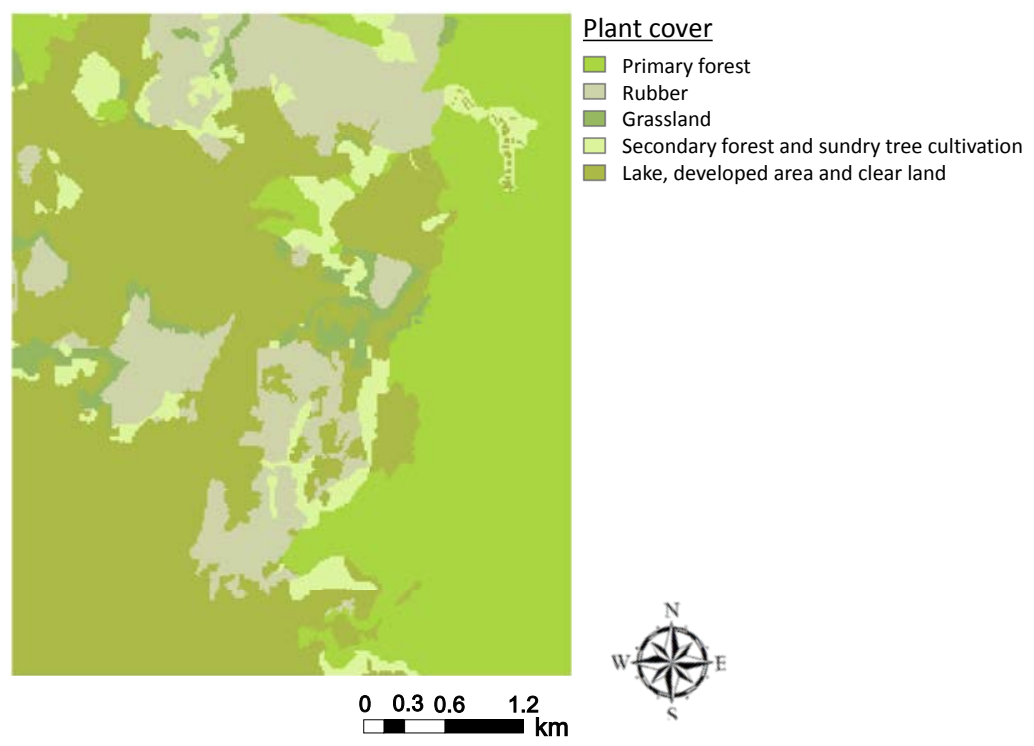

Figure 6. Map of plant cover.

In terms of hydrological cycle, the interception of rainfall is assumed to be part of the rainfall that is blocked by plant cover, forest floor, leaves and branches of the earth's surface and then evaporates. The evaporative rainfall here depends on plant cover characteristics, rainfall characteristics and evaporation demand. Although this study does not simulate the natural processes of rainfall blockage for primary forests $(24 \%)$, secondary forests $(23 \%)$, rubber $(19 \%)$, grassland $(23 \%)$ and grassland (17\% Rainfall blockage is being considered by the interception loss expected by Leaf Area Index (LAI).

\subsubsection{Rainfall Data}

The mean relative humidity of the study area is usually between $65 \%$ and $70 \%$ with temperature ranging from 29 to $32{ }^{\circ} \mathrm{C}$. The humidity is lowest from July to September and the temperature is highest from April to June. The monthly precipitation varies from 58 to $420 \mathrm{~mm}$. In this study area, there are two rainy seasons, one is from February to May and the other is from September to December [51]. The most highly precipitation falls between March and May and also from November to December. The study area generally has more than 200 rainy days per year. Dry seasons and wet seasons are both generally humid and in the wet season, there are 10 to 20 rainy days per month, while there are 10 to 15 rainy days per month in the dry season. The rainfall data used in this study are based on daily measured station data from 1990 to 2010 obtained from Malaysian Meteorological Department.

The rainfall interception loss also considered in the landslides analysis, calculated by using the plant cover and the relationships between LAI and distances from leaves to the ground. Plant cover map of the study area shown in Figure 6 and Table 2, a major data for determining LAI of each land class are used in this study [42].

Figure 7 shows the location of three rain gauge stations around the Hulu Kelang area, that is, Empangan Klang Gate Station, JPS Ampang Station and Bukit Antrabangsa Station. Figure 8a-c show the monthly rainfall with cumulative rainfall and daily rainfall in 2008, recorded by the rain gauges at the Empangan Klang Gate Station, JPS Ampang Station and Bukit Antrabansa Station. 


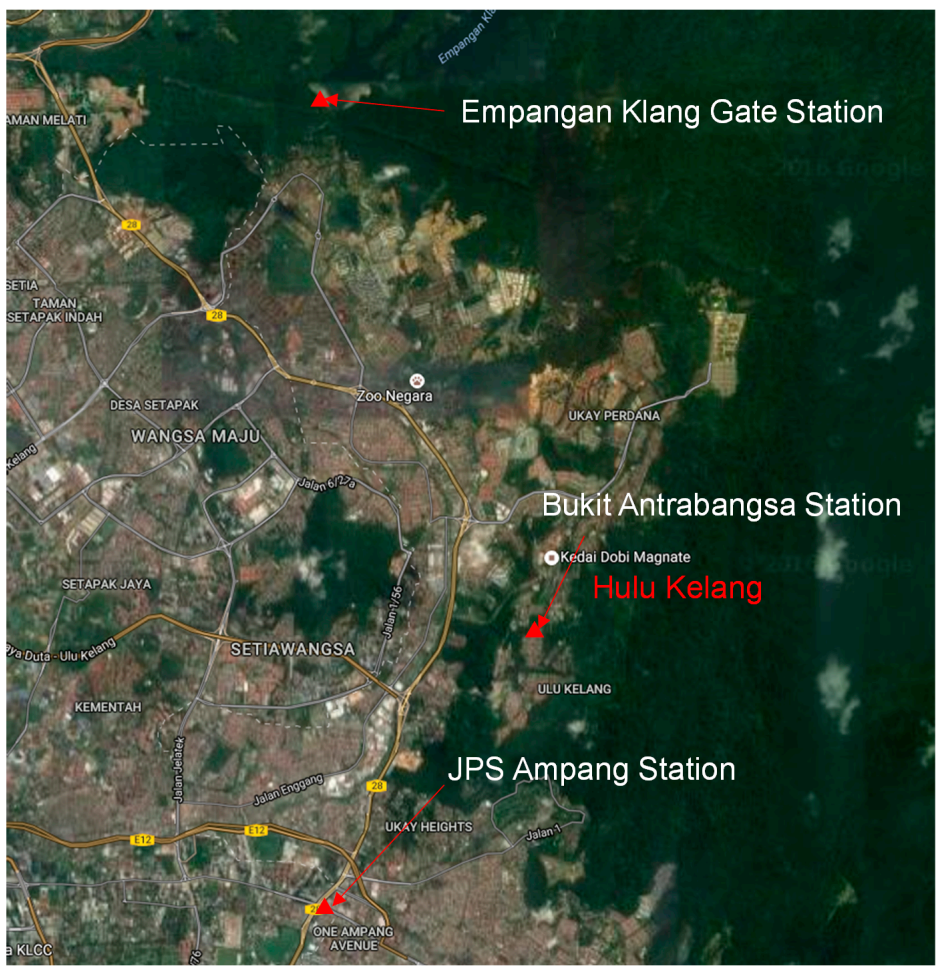

Figure 7. Rain gauge stations in Hulu Kelang area.
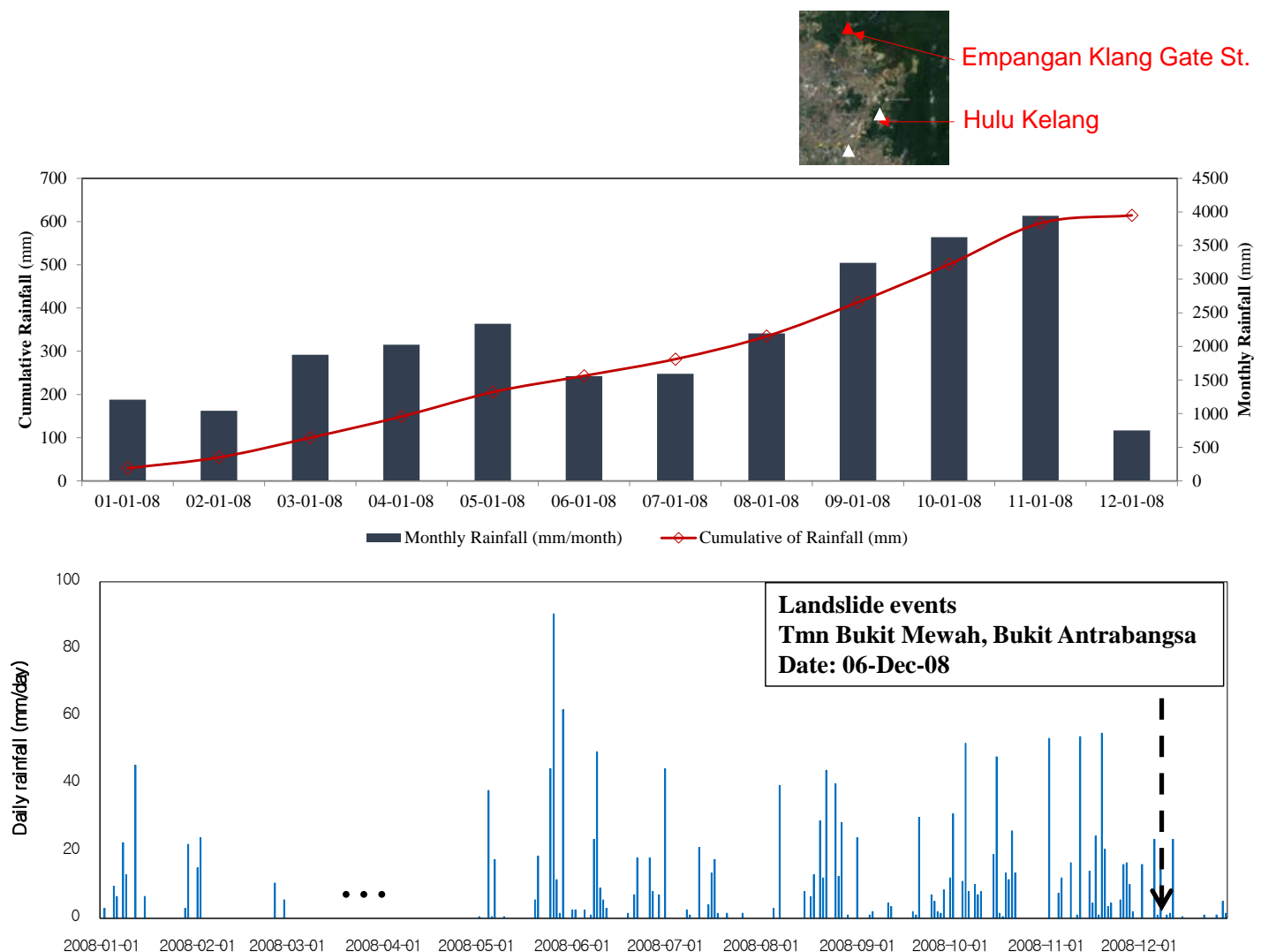

(a) Empangan Klang Gate Station

Figure 8. Cont. 

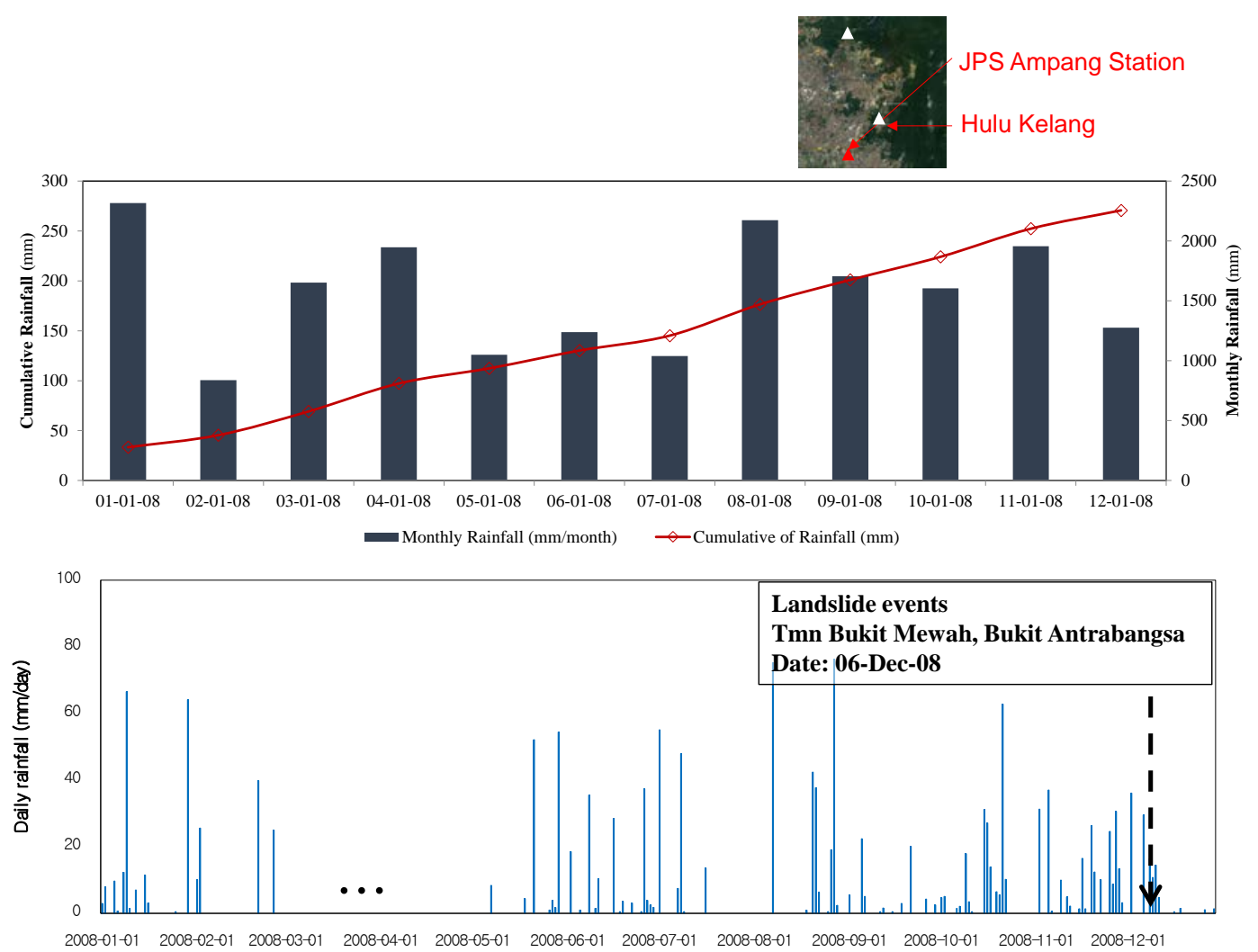

(b) JPS Ampang Station
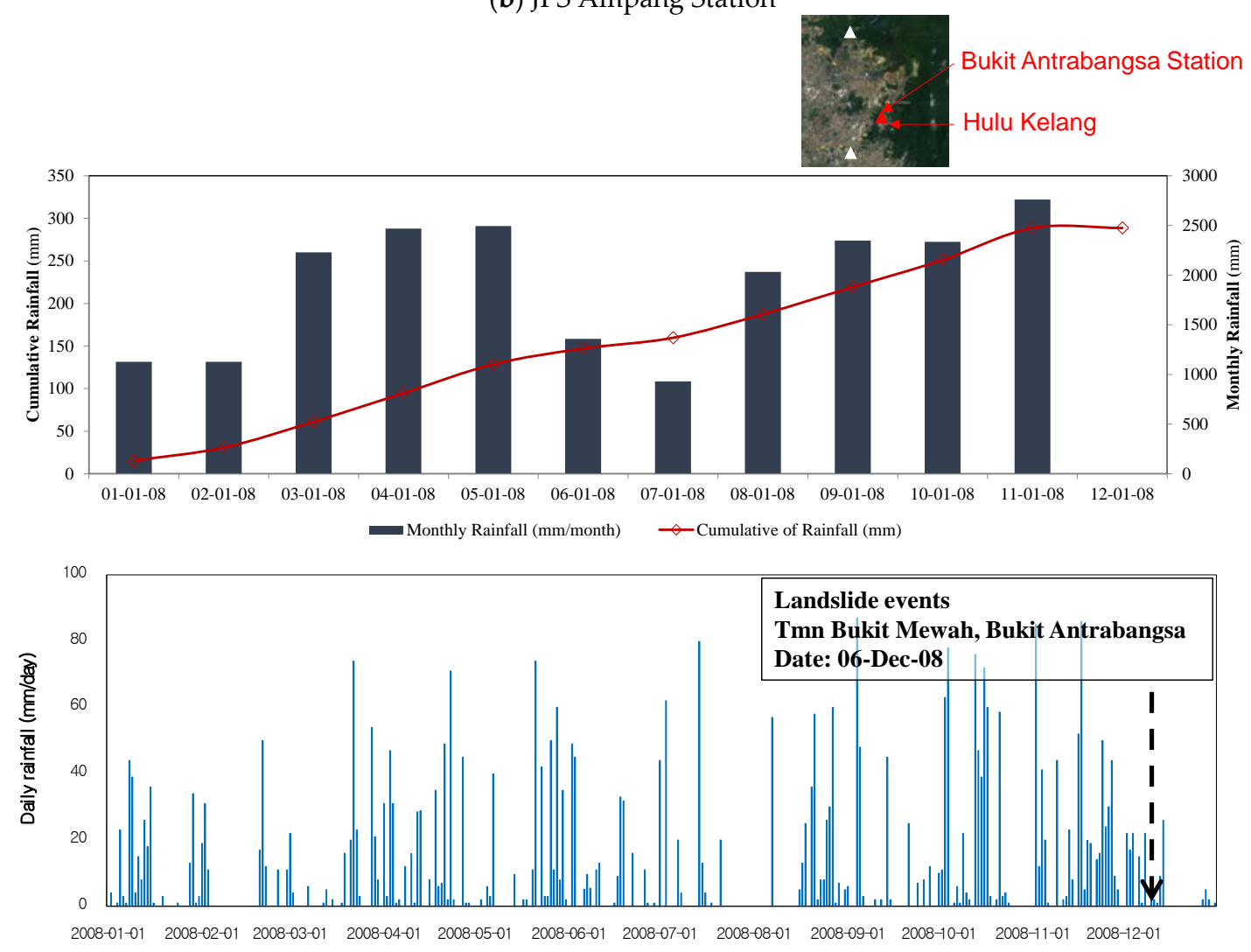

(c) Bukit Antrabangsa Station

Figure 8. Rainfall records in three rain gauge stations. 


\section{Results of Landslide Susceptibility Assessment}

A series of landslides analyses based on the YS-Slope model under rainstorm events were performed to estimate the landslide susceptibility of the study area. The results of the YS-Slope model were analyzed by comparing with the results of the previous study and the landslide histories in Hulu Kelang area. A $30 \times 30 \mathrm{~m}$ gridded DEM converted, soil properties obtained from field measurements and detailed investigations and precipitations gauged on the three stations were used as the input data stated above.

\subsection{Wetness Index}

Wetness index of the study area was predicted at the end of dry season, the end of the SW monsoon and the end of the NE monsoon. In this study, the wetness index was calculated by the groundwater table $\left(D_{w}\right)$, the wetting front depth $\left(Z_{w}\right)$ and the soil depth $(D)$, ranging from 0.0 to 1.0 as shown in Figure 9. The wetting front depth is a temporal saturated band under the ground surface and it was estimated by the rainfall-infiltration analysis. The wetting front depth at the end of dry season, the end of the SW monsoon and the end of the NE monsoon were described in Figure 10. The groundwater table is estimated by considering the recharge from the infiltrated water and groundwater flows. The groundwater table at the end of dry season, the end of the SW monsoon and the end of the NE monsoon were described in Figure 11. The wetting front depth is a major factor of the shallow landslides analysis and it is shown that the wetting front depth at the end of NE monsoon has high values compare with the end of dry season and the end of the SW season. As shown in Figure 10, areas that have low permeability represented by the soil zonation of STP2, LAACOL2, STP1 and MUM-SBN generally have large values of the wetting front depth and the values are also affected by the plant cover zonation. On the other hand, the groundwater table is a major factor of the deep-seated landslides analysis and it has generally higher values at the end of NE monsoon. As shown in Figure 11, it was found that the groundwater is concentrated in highly permeable areas such as LAACOL1, DLD and RGM. These results of the wetting front depth and the groundwater table was derived as the highly permeable soil cannot stay water for a long time and has short recharge time to groundwater. Figure 12 shows the results of the wetness index estimation in the study area. The wetness index was also maximized at the end of NE monsoon season with a value of 0.9 in the mountain area as shown in Figure 12. From the result of the wetness index, it is shown that long-term continuous rainfall causes the study area to be generally wet and this state would affect the landslide susceptibility of the mountainous area.

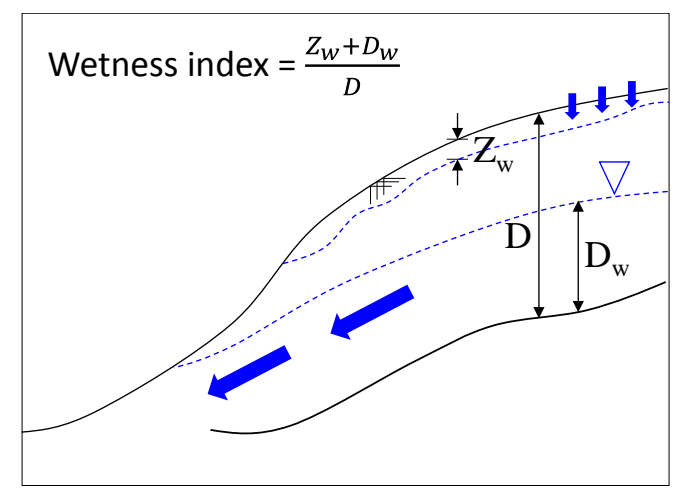

Figure 9. The definition of the wetness index. 


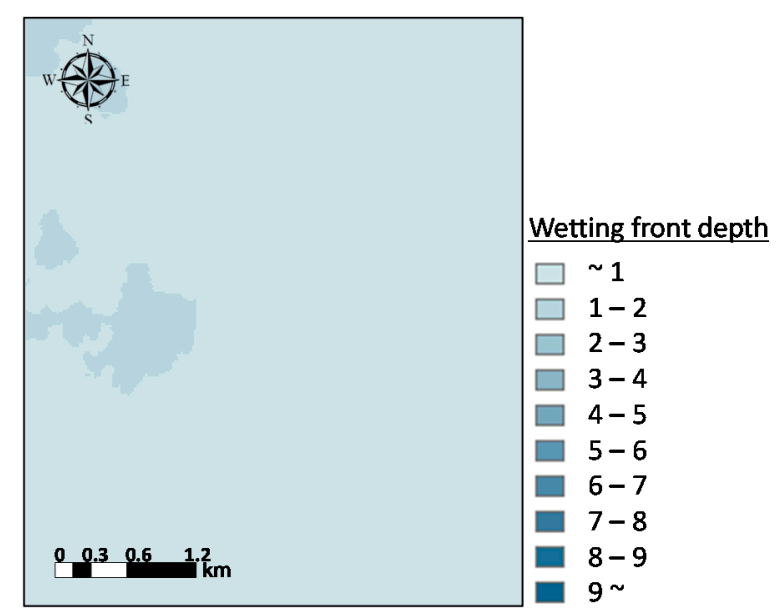

(a) The end of the dry season

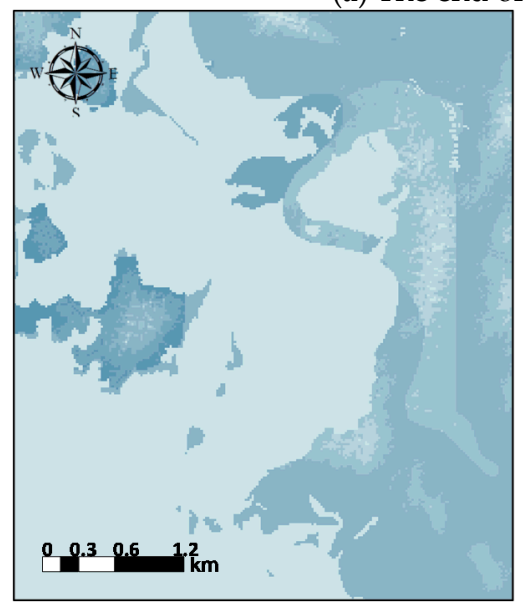

(b) The end of SW monsoon

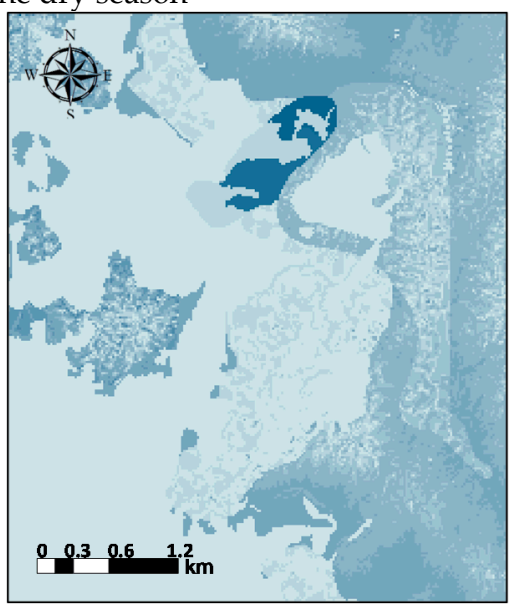

(c) The end of NE monsoon

Figure 10. Analytical results of the wetting front depth.

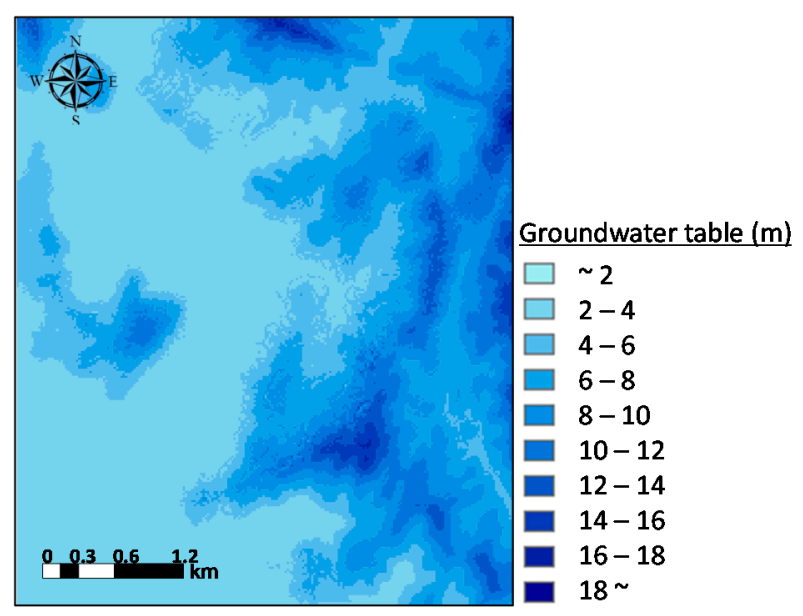

(a) The end of the dry season

Figure 11. Cont. 


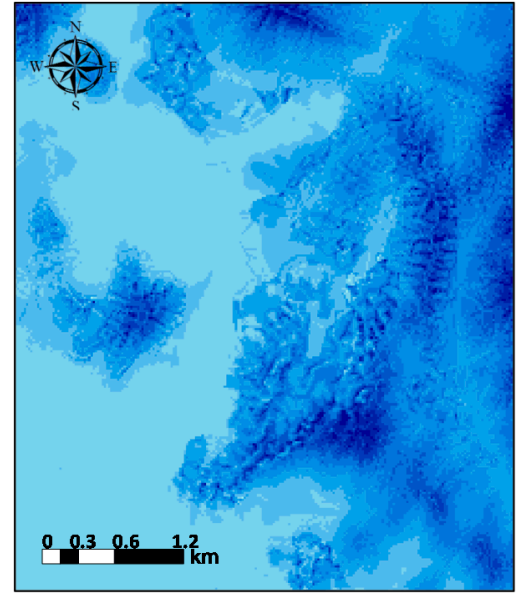

(b) The end of SW monsoon

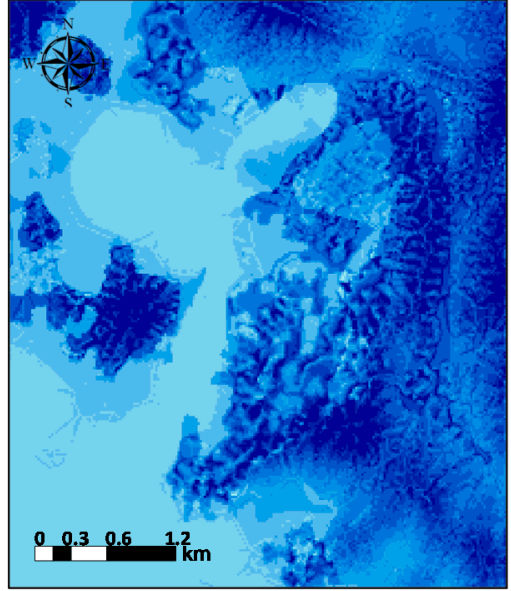

(c) The end of NE monsoon

Figure 11. Analytical results of the groundwater table.

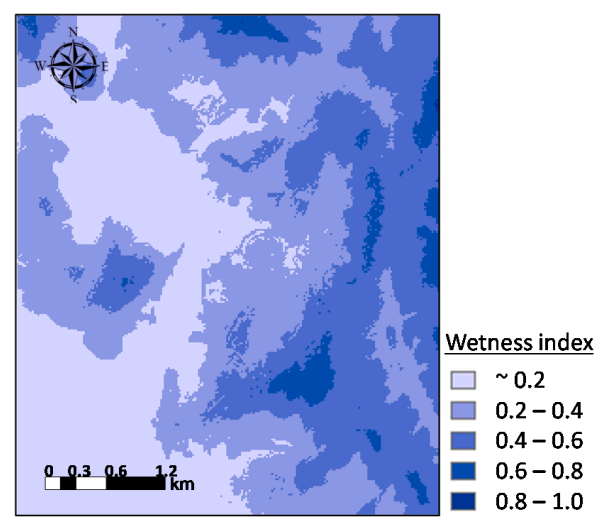

(a) The end of the dry season

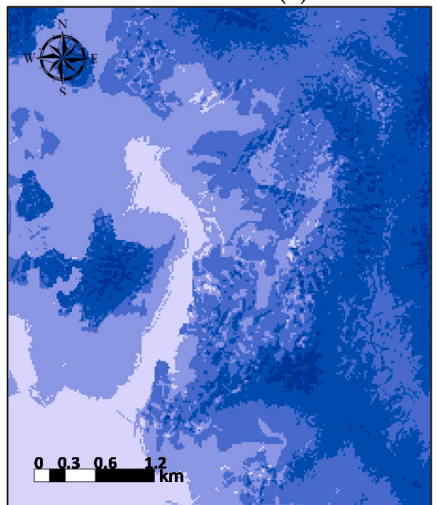

(b) The end of SW monsoon

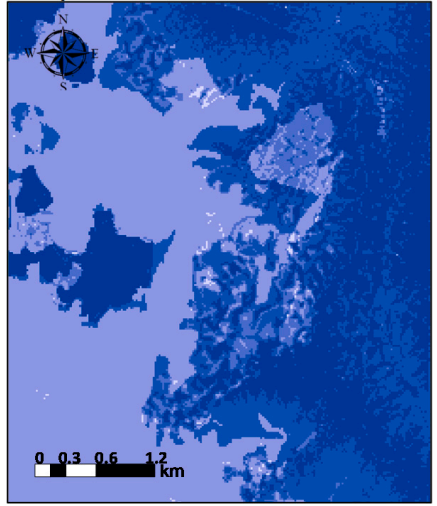

(c) The end of NE monsoon

Figure 12. Analytical results of the wetness index.

\subsection{Landslide Susceptibility Analysis}

Landslide susceptibility of the study area was predicted after the dry season, the end of the southwest monsoon and the end of the northeast monsoon as safety factors calculated by infinite slope failure model. Figures 13 and 14 shows that the result of landslide susceptibility analyses with two types of failure scenario. The first regime is defined as shallow landslides in depth of wetting front (Figure 13) and another condition is represented as deep slope failure events on the bedrock surface (Figure 14). The analytical results were compared with historical landslides (Yellow border) in this study area, as shown in Figures 13 and 14. As shown in Figure 15, according to the results of the 
study, shallow landslides due to failure under the wetting front mainly occurred in the central area, while deep-seated landslides due to failure on the bedrock were predominant in the east side of the study area. It can be also deduced that the prediction based on the shallow landslides analysis is more consistent by comparing the historical landslides.

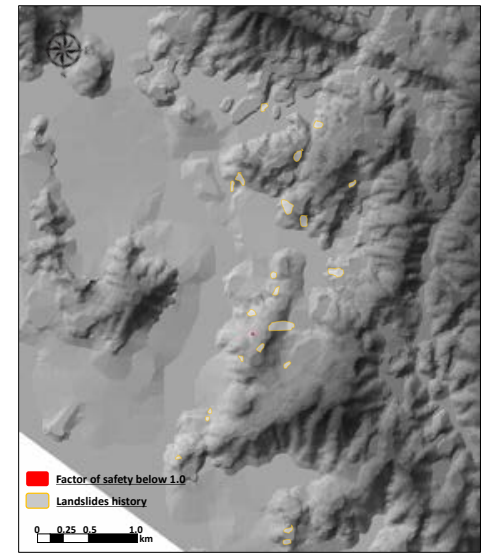

(a) The end of the dry season

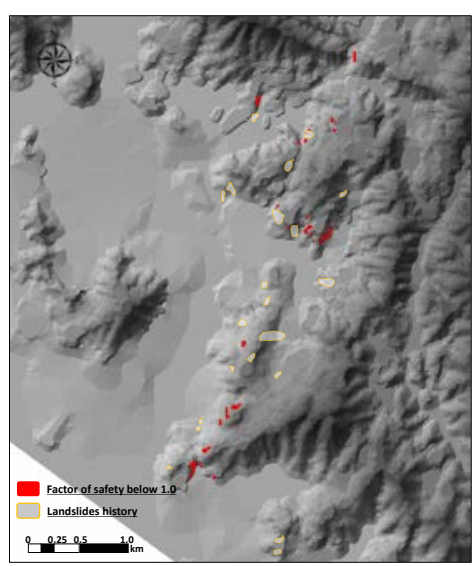

(b) The end of SW monsoon

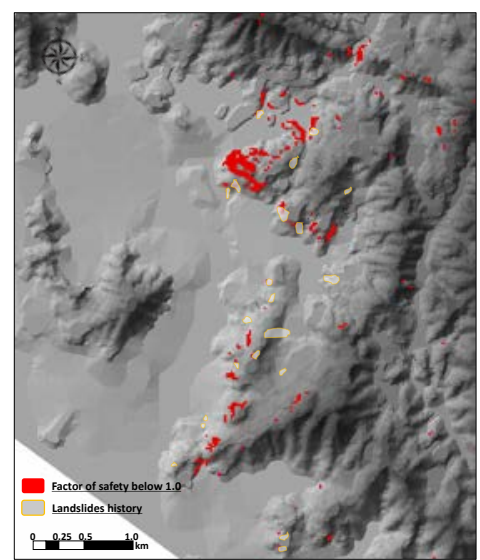

(c) The end of NE monsoon

Figure 13. Results of landslides analysis with Failure under the wetting front (shallow landslide).

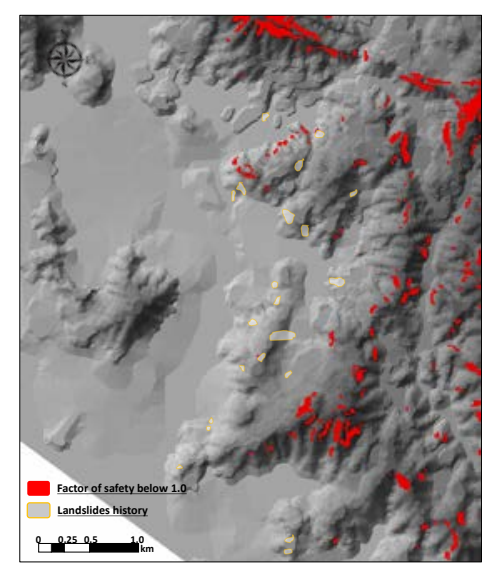

(a) The end of the dry season

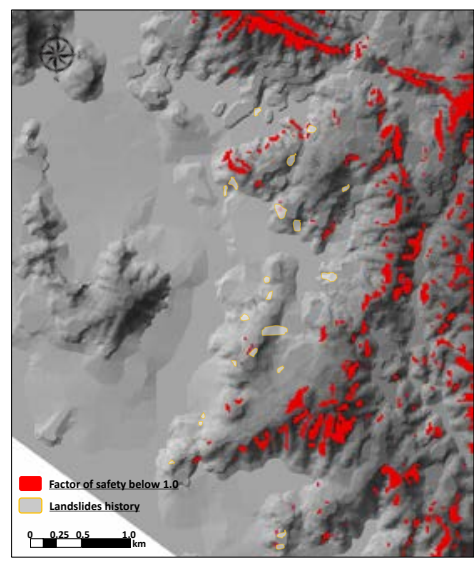

(b) The end of SW monsoon

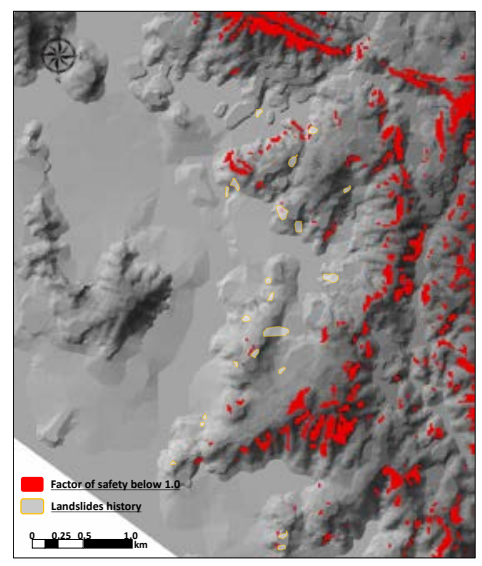

(c) The end of NE monsoon

Figure 14. Results of landslides analysis with Failure on the bedrock (deep-seated landslide).

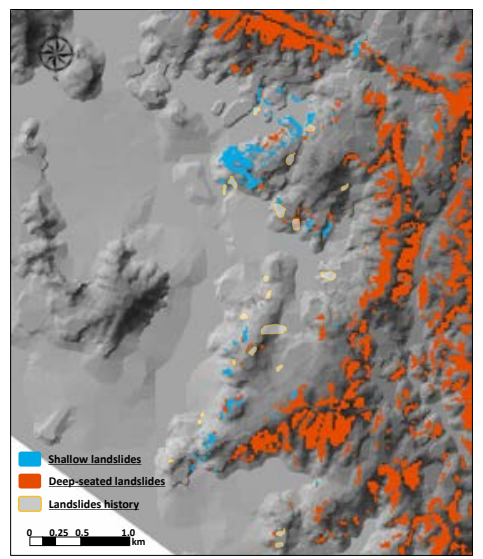

Figure 15. Comparison between the results of shallow and deep-seated landslides. 
In addition, Receiver operating characteristic (ROC) analysis was conducted to quantitatively analyze the results of this study. ROC analysis is a graph of the probability of correct prediction (Y-axis, true positive rate) versus probability of false prediction (X-axis, false positive rate). For the ROC analysis, the confusion matrix should be computed by comparing the analytical results with historical landslides and calculate TPR (True positive rate) and FPR (False positive rate). These parameters are estimated as follows:

$$
\begin{aligned}
& T P R=\frac{T P}{T P+F N} \\
& F P R=\frac{F P}{F P+T N}
\end{aligned}
$$

where $T P$ is the number of true positives number, $T N$ is true negatives, $F P$ is false positives and $F N$ is false negatives. The calculating results for ROC analysis were presented in Table 3 and the ROC graph was shown in Figure 16. In ROC graph, the distance between the point and the standard line $(y=x)$ represents the accuracy of the result of the analysis and the farther the point is from the standard line, the more accurate the prediction result. As a result of ROC analysis, it is shown that the analytical result at the end of the northeast monsoon for shallow landslides was relatively accurate.

\begin{tabular}{|c|c|c|c|c|c|c|}
\hline Time & Confusio & Matrix & & TPR & FPR & Distance to $\mathrm{y}=\mathrm{x}$ Line \\
\hline \multirow{2}{*}{$\begin{array}{l}\text { End of dry season } \\
\text { (shallow) }\end{array}$} & Occurrence $\quad$ Prediction & Positive & Negative & \multirow{2}{*}{0} & \multirow{2}{*}{0} & \multirow{2}{*}{0} \\
\hline & No & 0 & 36,815 & & & \\
\hline \multirow{2}{*}{$\begin{array}{l}\text { End of SW monsoon } \\
\text { (shallow) }\end{array}$} & Prediction & Positive & Negative & \multirow{2}{*}{0.186} & \multirow{2}{*}{$5.16 \times 10^{-04}$} & \multirow{2}{*}{0.131} \\
\hline & No & 19 & 36,796 & & & \\
\hline \multirow{3}{*}{$\begin{array}{l}\text { End of NE monsoon } \\
\text { (shallow) }\end{array}$} & $\begin{array}{ll} & \text { Prediction } \\
\text { Occurrence } & \end{array}$ & Positive & Negative & \multirow{3}{*}{0.769} & \multirow{3}{*}{$5.79 \times 10^{-03}$} & \multirow{3}{*}{0.539} \\
\hline & Yes & 83 & 25 & & & \\
\hline & No & 213 & 36,602 & & & \\
\hline $\begin{array}{l}\text { End of dry season } \\
\text { (deep-seated) }\end{array}$ & No & 3446 & 33,369 & 0.551 & 0.094 & 0.323 \\
\hline \multirow{4}{*}{$\begin{array}{l}\text { End of SW monsoon } \\
\text { (deep-seated) }\end{array}$} & Prediction & Positive & Negative & \multirow{4}{*}{0.722} & \multirow{4}{*}{0.154} & \multirow{4}{*}{0.401} \\
\hline & & & & & & \\
\hline & Yes & 70 & 27 & & & \\
\hline & No & 5664 & 31,151 & & & \\
\hline \multirow{3}{*}{$\begin{array}{l}\text { End of NE monsoon } \\
\text { (deep-seated) }\end{array}$} & Occurrence $\quad$ Prediction & Positive & Negative & \multirow{3}{*}{0.791} & \multirow{3}{*}{0.243} & \multirow{3}{*}{0.388} \\
\hline & Yes & 91 & 24 & & & \\
\hline & No & 8933 & 27,882 & & & \\
\hline
\end{tabular}

Table 3. The calculating results for ROC analysis. 


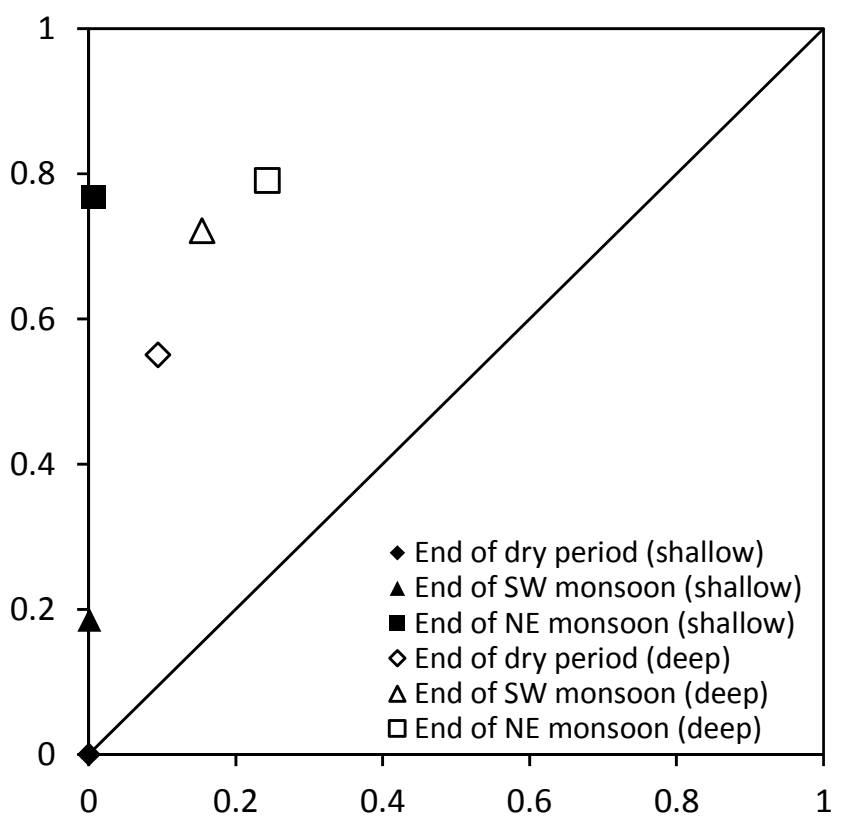

Figure 16. The ROC graph for the analytical results.

Additionally, the results of this study were compared with the previous analysis using Transient Rainfall Infiltration and Grid-Based Regional Slope Stability (TRIGRS) and modified TRIGRS [40]. Saadatkhah et al. (2016) performed the slope stability analysis by using TRIGRS model and modified TRIGRS to improve the analysis with consideration of the effects of plant cover. Based on false positives and false negatives presented by Saadatkhah et al. (2016), we compared the landslides prediction results by TRIGRS, modified TRIGRS and YS-Slope as shown in Table 4. In comparison with previous research results, we applied the result of shallow landslides prediction at the end of northeast monsoon season which showed the highest accuracy through ROC analysis in this study. From the comparison of this study and the previous research, for the YS-Slope used in this study, the false positive is relatively small, while the false negative is higher than the conventional models. It can be interpreted that the sensitivity is high but the specificity is low in landslide prediction.

Table 4. Comparison of results with previous research.

\begin{tabular}{cccccc}
\hline \multirow{2}{*}{ Depth } & False Evaluation & TRIGRS (\%) & Improved TRIGRS (\%) & $\begin{array}{c}\text { YS-Slope (\%) } \\
\text { [Depth = Wetting Front Depth] }\end{array}$ \\
\hline \multirow{2}{*}{$4 \mathrm{~m}$} & False positive & 30.09 & 29.08 & False positive & 0.58 \\
\multirow{2}{*}{$8 \mathrm{~m}$} & False negative & 12.25 & 4.83 & \multirow{2}{*}{ False negative } & 23.15 \\
& False positive & 23.13 & 17.08 & & \\
& False negative & 21.03 & 10.04 & & \\
\hline
\end{tabular}

\section{Conclusions}

This study provides the regional scale susceptibility assessment of landslides in Hulu Kelang area, Kuala Lumpur, Malaysia by using a GIS-based landslides prediction model named YS-Slope [37]. This model uses unsaturated soil characteristics like the field matric suction and SWCC (Soil Water Characteristic Curve), as well as the soil strength properties. In addition, the model reflects the influence of the increased soil strength and load and interception loss due to vegetation. From the result of rainfall infiltration and groundwater flow analysis, we can calculate the wetting state of the ground and assess the susceptibility of landslides based on various data such as DEM, soil depth, slope. The following conclusions have been deduced from the findings of this study: 
1. All raster maps of DEM, soil depth, initial groundwater table and slope were used to analyze the susceptibility of landslides in Hulu Kelang area and soil hydrological and mechanical characteristic and plant covers were applied as important factors in calculating the factor of safety. One year precipitation from Bukit Antrabangsa station which located closest to Hulu Kelang area was used as the rainfall input data.

2. YS-Slope model, the model used in this study has clearly simulated two types of the rainfall-induced landslide. One is the shallow landslide and another is the deep-seated landslide. According to the results of the study, shallow landslides due to failure under the wetting front mainly occurred in the central area, while deep-seated landslides due to failure on the bedrock were predominant in the east side of the study area. It can be also deduced that the prediction based on the shallow landslides analysis is more consistent by comparing the historical landslides.

3. The ROC analysis was conducted to quantitatively analyze the results of this study. Each analytical results of landslides susceptibility analysis for the end of dry season, the end of SW monsoon and the end of NE monsoon were evaluated by ROC analysis. As a result of ROC analysis, it is shown that the analytical result at the end of northeast monsoon for shallow landslides has the highest value of the distance from the standard line $(y=x)$. This result means that the prediction based on the result at the end of northeast monsoon for shallow landslides is more accurate compared with other results.

4. In comparison with previous research results by the result of shallow landslides prediction at the end of northeast monsoon season which has the highest accuracy, the false positive is very small, while the false negative is higher than the conventional models. It can be interpreted that the sensitivity is high but the specificity is low in landslide prediction compared with the previous research results.

Author Contributions: A.K. conceived and designed the experiments; N.S. performed the experiments; S.J. and M.H. analyzed the data; S.J. and M.H. contributed reagents/materials/analysis tools; M.H. wrote the paper. Authorship must be limited to those who have contributed substantially to the work reported.

Funding: This work was supported by a National Research Foundation of Korea (NRF) grant funded by the Korean government (MSIP) (No. 2011-0030040), Basic Science Research Program through the National Research Foundation of Korea (NRF) funded by the Ministry of Education (No. 2018R1A6A1A08025348) and the Graduate School of YONSEI University Research Scholarship Grants in 2017.

Conflicts of Interest: The authors declare no conflicts of interest.

\section{References}

1. Baek, S.C.; Kang, I.K.; Kim, H.T.; Sim, Y.J. An experimental study on the variation of pore-water pressure in soil slope during the rainfall. Int. J. Geo-Eng. 2012, 4, 35-42.

2. Wang, Q.; Wang, D.; Huang, Y.; Wang, Z.; Zhang, L.; Guo, Q.; Sang, M. Landslide susceptibility mapping based on selected optimal combination of landslide predisposing factors in a large catchment. Sustainability 2015, 7, 16653-16669. [CrossRef]

3. Zhou, S.; Chen, G.; Fang, L.; Nie, Y. GIS-based integration of subjective and objective weighting methods for regional landslides susceptibility mapping. Sustainability 2016, 8, 334. [CrossRef]

4. Kim, H.G.; Lee, D.K.; Park, C. Assessing the Cost of Damage and Effect of Adaptation to Landslides Considering Climate Change. Sustainability 2018, 10, 1628. [CrossRef]

5. Saadatkhah, N.; Kassim, A.; Lee, L.M. Qualitative and quantitative landslide susceptibility assessments in Hulu Kelang area, Malaysia. EJGE 2014, 19, 545-563.

6. Hammond, C.J.; Prellwitz, R.W.; Miller, S.M. Landslide hazard assessment using Monte Carlo simulation. In Proceedings of the 6th International Symposium on Landslides, Christchurch, New Zealand, 10-14 February 1992; Balkema: Rotterdam, The Netherlands, 1992; Volume 2, pp. 251-294.

7. Montgomery, D.R.; Dietrich, W.E. A physically based model for the topographic control on shallow landsliding. Water Resour. Res. 1994, 30, 1153-1171. [CrossRef] 
8. Mantovani, F.; Soeters, R.; Van Westen, C.J. Remote sensing techniques for landslide studies and hazard zonation in Europe. Geomorphology 1996, 15, 213-225. [CrossRef]

9. Van Westen, C.J. Statistical landslide hazard analysis. ILWIS 1997, 2, 73-84.

10. Tucker, G.E.; Catani, F.; Rinaldo, A.; Bras, R.L. Statistical analysis of drainage density from digital terrain data. Geomorphology 2001, 36, 187-202. [CrossRef]

11. Dai, F.C.; Lee, C.F.; Ngai, Y.Y. Landslide risk assessment and management: An overview. Eng. Geol. 2002, 64, 65-87. [CrossRef]

12. Baum, R.L.; Savage, W.; Godt, J.W. TRIGRS—A Fortran Program for Transient Rainfall Infiltration and Grid-Based Regional Slope Stability Analysis; Open-File Report 02-0424; USGS: Reston, VA, USA, 2002; p. 35.

13. Zhou, G.; Esaki, T.; Mitani, Y.; Xie, M.; Mori, J. Spatial probabilistic modeling of slope failure using an integrated GIS Monte Carlo simulation approach. Eng. Geol. 2003, 68, 373-386. [CrossRef]

14. Metternicht, G.; Hurni, L.; Gogu, R. Remote sensing of landslides: An analysis of the potential contribution to geo-spatial systems for hazard assessment in mountainous environments. Remote Sens. Environ. 2005, 98, 284-303. [CrossRef]

15. Huabin, W.; Gangjun, L.; Weiya, X.; Gonghui, W. GIS-based landslide hazard assessment: An overview. Prog. Phys. Geogr. 2005, 29, 548-567. [CrossRef]

16. Gupta, R.P.; Joshi, B.C. Landslide hazard zoning using the GIS approach-a case study from the Ramganga catchment, Himalayas. Eng. Geol. 1990, 28, 119-131. [CrossRef]

17. Borrelli, L.; Ciurleo, M.; Gullà, G. Shallow landslide susceptibility assessment in granitic rocks using GIS-based statistical methods: The contribution of the weathering grade map. Landslide 2018, 15, 1127-1142. [CrossRef]

18. Cascini, L.; Ciurleo, M.; Di Nocera, S.; Gullà, G. A new-old approach for shallow landslide analysis and susceptibility zoning in fine-grained weathered soils of southern Italy. Geomorphology 2015, 241, 371-381. [CrossRef]

19. Ciurleo, M.; Calvello, M.; Cascini, L. Susceptibility zoning of shallow landslides in fine grained soils by statistical methods. Catena 2016, 139, 250-264. [CrossRef]

20. Ciurleo, M.; Cascini, L.; Calvello, M. A comparison of statistical and deterministic methods for shallow landslide susceptibility zoning in clayey soils. Eng. Geol. 2017, 223, 71-81. [CrossRef]

21. Hong, M.; Kim, J.; Jeong, S. Rainfall intensity-duration thresholds for landslide prediction in South Korea by considering the effects of antecedent rainfall. Landslides 2018, 15, 523-534. [CrossRef]

22. Lu, N.; Godt, J. Infinite slope stability under steady unsaturated seepage conditions. Water Resour. Res. 2008, 44. [CrossRef]

23. Fredlund, D.G.; Morgenstern, N.R.; Widger, R.A. The shear strength of unsaturated soils. Can. Geotech. J. 1978, 15, 313-321. [CrossRef]

24. Jeong, S.; Lee, K.; Kim, J.; Kim, Y. Analysis of rainfall-induced landslide on unsaturated soil slopes. Sustainability 2017, 9, 1280. [CrossRef]

25. Kim, Y.; Park, H.; Jeong, S. Settlement Behavior of Shallow Foundations in Unsaturated Soils under Rainfall. Sustainability 2017, 9, 1417. [CrossRef]

26. Kim, J.; Kim, Y.; Jeong, S.; Hong, M. Rainfall-induced landslides by deficit field matric suction in unsaturated soil slopes. Environ. Earth Sci. 2017, 76, 808. [CrossRef]

27. Jeong, S.; Kim, Y.; Lee, J.K.; Kim, J. The 27 July 2011 debris flows at Umyeonsan, Seoul, Korea. Landslides 2015, 12, 799-813. [CrossRef]

28. Cotecchia, F.; Santaloia, F.; Lollino, P.; Vitone, C.; Mitaritonna, G. Deterministic landslide hazard assessment at regional scale. In GeoFlorida 2010: Advances in Analysis, Modeling \& Design; ASCE Library: Reston, VA, USA, 2010; pp. 3130-3139.

29. Pardeshi, S.D.; Autade, S.E.; Pardeshi, S.S. Landslide hazard assessment: Recent trends and techniques. SpringerPlus 2013, 2, 523. [CrossRef] [PubMed]

30. Brabb, E.E. Proposal for worldwide landslide hazard maps. In Proceedings of the 7th International Conference and Field Workshop on Landslides, Rotterdam, The Netherlands, 28 August-15 September 1993; Novosad, S., Wagner, P., Eds.; Balkema: Rotterdam, The Netherlands; pp. 15-27.

31. Burrough, P.A. Principles of Geographical Information Systems for Land Resources Assessment; Claredon Press: Oxford, UK, 1986; p. 194. 
32. Van Westen, C.J. Application of Geographic Information Systems to Landslide Hazard Zonation; ITC Enschede: Enschede, The Netherlands, 1993.

33. Tarboton, D.G. A New Method for the Determination of Flow Directions and Contributing Areas in Grid Digital Elevation Models. Water Resour. Res. 1997, 33, 309-319. [CrossRef]

34. Simoni, S.; Zanotti, F.; Bertoldi, G.; Rigon, R. Modelling the probability of occurrence of shallow landslides and channelized debris flows using GEOtop-FS. Hydrol. Process. 2008, 22, 532-545. [CrossRef]

35. Montrasio, L.; Valentino, R.; Losi, G.L. Towards a real-time susceptibility assessment of rainfall-induced shallow landslides on a regional scale. Nat. Hazards Earth Syst. Sci. 2011, 11, 1927-1947. [CrossRef]

36. Lepore, C.; Arnone, E.; Noto, L.V.; Sivandran, G.; Bras, R.L. Physically Based Modeling of Rainfall-Triggered Landslides: A Case Study in the Luquillo Forest, Puerto Rico. Hydrol. Earth Syst. Sci. 2013, 17, 3371-3387. [CrossRef]

37. Kim, J.; Lee, K.; Jeong, S.; Kim, G. GIS-based prediction method of landslide susceptibility using a rainfall infiltration-groundwater flow model. Eng. Geol. 2014, 182, 63-78. [CrossRef]

38. Green, W.H.; Ampt, G. Studies on soil physics, 1. The flow of air and water through soils. J. Agric. Sci. 1911, 4, 1-24.

39. Mein, R.G.; Larson, C.L. Modeling infiltration during a steady rain. Water Resour. Res. 1973, 9, $384-394$. [CrossRef]

40. Soller, D.; Duncan, I.; Ellis, G.; Giglierano, J.; Hess, R. Proposed guidelines for inclusion of digital map products in the National Geologic Map Database. In Proceedings of the Digital Mapping Techniques'99, Madison, WI, USA, 19-22 May 1999; Workshop US Geological Survey Open-File Report; USGS: Reston, VA, USA, 1999; pp. 99-386.

41. Ali, F. Unsaturated tropical residual soils and rainfall induced slopes in Malaysia. In Proceedings of the Asian Conference on Unsaturated Soils, Singapore, 18-19 May 2000; Volume 41, pp. 18-19.

42. Saadatkhah, N.; Mansor, S.; Kassim, A.; Lee, L.M.; Saadatkhah, R.; Sobhanmanesh, A. Regional modeling of rainfall-induced landslides using TRIGRS model by incorporating plant cover effects: Case study in Hulu Kelang, Malaysia. Environ. Earth Sci. 2016, 75, 445. [CrossRef]

43. Stek, P.E. Urban Groundwater Extraction in Kuala Lumpur, Malaysia. Master's Thesis, Civil Engineering and Management, University of Twente, Enschede, The Netherlands, 2008.

44. Anderson, M.G.; Burt, T.P. The role of topography in controlling through flow generation. Earth Surf. Process. 1978, 3, 331-344. [CrossRef]

45. Koler, T.E. Evaluating slope stability in forest uplands with deterministic and probabilistic models. Environ. Eng. Geosci. 1998, 4, 185-194. [CrossRef]

46. Schmidt, K.M.; Roering, J.J.; Stock, J.D.; Dietrich, W.E.; Montgomery, D.R.; Schaub, T. The variability of root cohesion as an influence on shallow landslide susceptibility in the Oregon Coast Range. Can. Geotech. J. 2003, 40, 237-253. [CrossRef]

47. Stokes, A.; Norris, J.E.; Van Beek, L.P.H.; Bogaard, T.; Cammeraat, E.; Mickovski, S.B.; Jenner, A.; Iorio, A.; Fourcaud, T. How Vegetation Reinforces Soil. Slope Stability and Erosion Control: Ecotechnological Solutions; Springer: Berlin, Germany, 2008; pp. 65-118.

48. Cancienne, R.; Fox, G.A.; Simon, A. Influence of seepage undercutting on the root reinforcement of streambanks. Earth Surf. Proc. Landf. 2008, 33, 1769-1786. [CrossRef]

49. Hoffman, J.R.; Stout, J.R. Performance-enhancing substances. In Essentials of Strength and Conditioning, 3rd ed.; Earle, R.W., Baechle, T.R., Eds.; Human Kinetics: Champaign, IL, USA, 2008; pp. 179-200.

50. Sonnenberg, R.; Bransby, M.F.; Hallett, P.D.; Bengough, A.G.; Mickovski, S.B.; Davies, M.C.R. Centrifuge modelling of soil slopes reinforced with vegetation. Can. Geotech. 2010, 47, 1415-1430. [CrossRef]

51. Lee, M.L.; Ng, K.Y.; Huang, Y.F.; Li, W.C. Rainfall-induced landslides in Hulu Kelang area, Malaysia. Nat. Hazards 2014, 70, 353-375. [CrossRef]

(C) 2018 by the authors. Licensee MDPI, Basel, Switzerland. This article is an open access article distributed under the terms and conditions of the Creative Commons Attribution (CC BY) license (http:/ / creativecommons.org/licenses/by/4.0/). 